\title{
Environmental Contamination of Arsenic and its Toxicological Impact in Cardiovascular Tissues of Patients with Coronary Heart Disease
}

\author{
Isabel Pizarro ${ }^{1}$, Domingo Román ${ }^{2}$, Carlos Solar $^{3}$ \\ ${ }^{1,2}$ Laboratory of Bioinorganic and Environmental Analytical Chemistry, Department of Chemistry. Faculty of Basic Sciences. Universidad \\ de Antofagasta, Av. Universidad de Antofagasta 02800(Chile) \\ ${ }^{3}$ Unity of Cardiovascular Surgery. ClínicaAntofagasta, Manuel AntonioMatta 1810, Antofagasta (Chile)
}

\begin{abstract}
Background: The concentration levels of As in the Chilean II Region of Antofagasta produces non cancer health outcomes such as cardiovascular diseases and in last term heart attack. On this study, the determination of total As content and main inorganic and organoarsenic species found in three heart tissues (auricle, mammary artery and fat) and the saphenous vein of people living in the Chilean II Region, suffering coronary thrombosis has been carried out. Comparison with similar tissues of patients from other noncontaminated areas has been undertaken. Methods: Total As determination has been performed by HG-AAS and ICP-MS. For As species have been used the tandem HPLC-ICP-MS using the Hamilton PRP X100 anion column and methanol:water (1:1) extraction. Results: The auricle and in less extend the saphenous vein support the higher As concentration (mean values of 7.7 and $2.5 \mu g g^{-1}$, respectively), being As(III) the predominant species. Methylation towards MMA and DMA is not a favoured mechanism. Conclusions: The presence of high total As and high As(III) species content in the auricle and saphenous vein of more contaminated people, the damage found in the saphenous vein tissue and the global characteristics of the people under study in which the As stigmas are present in all of them, suggests that As could be involved in the cardiovascular diseases.
\end{abstract}

Keywords: Arsenic, Cardiovascular Dideases, HPLC-ICP-MS

\section{Introduction}

The coastal - AndeanMountain - Upper Highlands Ecosystem of the II Region of Chile is an important area of the Atacama Desert; of which the River Loa basin is a part. This river is an aquatic desert ecosystem, and the source of drinking water for the cities in the II Region of Antofagasta in Chile. However, this particular ecosystem suffers from the chronic impact of endogenous arsenic due to volcanism in the area, and anthropogenic delivery of arsenic and other heavy metal due to mining activity (1), which transport trace elements more rapidly into ecosystem in comparison to the normal geological process, thus spreading the heavy metals to human beings, through the biogeochemical cycles (2).

To overcome the effect of arsenic on water quality, arsenicreduction plants have been in operation since 1972 for the principal cities of Antofagasta. Despite this, the effect of arsenic on human health has been noticeable in relation to cancer effects (3) and the incidence of cardiovascular diseases (CVD), which are recognized as typical non-cancer effects due to arsenic exposure (4).

Naturally occurring arsenic in the Antofagasta region at North of Chile is due to volcanic activity during the tertiary and quaternary periods in the Andes Mountain, and heavy metals delivery is principally due to copper mining activity (5), which favours the arsenic enrichment of underground and surface waters. The most extensive copper production and contamination with arsenic occur in the area between $17^{\circ} 30^{\prime}$ and $26^{\circ} 05^{\prime}$ 'south latitude and between $67^{\circ} 00^{\prime}$ west longitude and the Pacific Ocean, usually at altitudes higher than 2,000 $\mathrm{m}$ above sea level (6). Small, median and great mining in this area produces over $50 \%$ of the copper that is mined in the world. This is the reason why the Antofagasta region is called the "mining capital of Chile" (Figure 1). Mining activity mobilized heavy metals into the environment at rates greatly exceeding those of natural geological processes, disturbing biogeochemical cycles, copper smelting and sulphuric acid plants generate significant emissions of $\mathrm{SO}_{2}$, arsenic and others heavy metals into the atmosphere, also diffuse pollution may be responsible for the contamination of the environment by toxic pollutants (7).

The average concentration of arsenic in the drinking water of Antofagasta was approximately $800 \mu \mathrm{g} / \mathrm{L}$ during 1950 1970 (8). After installation of arsenic-reduction plants, the arsenic concentration in drinking water of the principal cities of the Antofagasta region decreased to $50 \mu \mathrm{g} / \mathrm{L}$, which it is the maximum level of arsenic in water recommended by the Chilean government. However, there are towns that consume drinkable water with arsenic levels over $50 \mathrm{ppb}(8)$. Recently, the efficiency of arsenic-removal plants in the Antofagasta region has improved, providing drinking water with arsenic concentrations less than $50 \mu \mathrm{g} / \mathrm{L}$, but higher 10 $\mu \mathrm{g} / \mathrm{L}$, which is the maximum tolerable level according to index guidance recommended by the World Health Organization (WHO) (9).

The chronic impact of arsenic in the Antofagasta region produces cancer and non-cancer outcomes, and increases the teratogenicity risk of foetal and infant mortality (10); arsenic can easily cross the placentas of humans and animals (11) ad also it is a neurological agent (12). Cancer effects (13) are similar to those described in other countries affected by arsenic in the environment (14). According Smith (15) and Marshall (3), the impact of arsenic on the population due 


\section{International Journal of Science and Research (IJSR) \\ ISSN (Online): 2319-7064}

Index Copernicus Value (2016): 79.57 | Impact Factor (2015): 6.391

cancer mortality in the region of Antofagasta in Chile, is greater than reported for any other country to date as a consequence of environmental exposure to carcinogens in a major population, even though major decreases in arsenic exposure occurred more than 25 years earlier due to plants of arsenic depression. Increased lung cancer risk is similar whether arsenic is ingested or inhaled (16).

Typical clinical non-cancer effects affecting the health and quality of life of people due to environmental arsenic exposure, such as vascular diseases, abnormal pigmentation, Reynard's syndrome, acrocyanosis, hyperkeratosis, finger gangrene, tongue ischemia, diabetes, thrombosis, cerebral vascular disease (particularly cerebral strokes), coronary artery occlusions, and other CVDs have been associated to the arsenic chronic exposure $(17,18)$. However, other factors of risk like smoking, serum high levels of lowdensity lipoprotein (LDL cholesterol) and high blood pressure levels have been associated cooperatively with the coronary heart disease (CHD) or cardiovascular atherosclerotic disease in humans. On the other hand, actually it is becoming increasingly evident that low or moderate level exposure to arsenic is widely prevalent (19) for cardiovascular risk. Therefore, it is necessary to obtain more direct evidence about the fate of arsenic in cardiovascular tissues.

The mechanism across mammalian animals including man metabolises and detoxify inorganic As is methylation to methylarsonate and dimethylarsinate (20). Before this methylation arsenate must be reduced to arsenite; the binding of arsenite to tissue proteins would be an additional or perhaps the first step in the detoxification of inorganic As prior to methylation (21). Therefore, before methylation, increases the in vivo toxicity and risk to the organism (21). Otherwise, recently has been informed that biomethylation being a process that potentiates toxicity and carcinogenicity of inorganic arsenic (22).

In healthy humans exposed to trace amounts of arsenic, the highest concentrations are found in tissues rich in sulfhydryl groups (e.g. skin, hair, nails). Little is known about the total concentration of arsenic in the organs of individuals not exposed to trace amounts of arsenic (23). Median arsenic concentrations (in dry weight) in the organs of healthy people range from $0.012 \mu \mathrm{g} / \mathrm{g}$ in the brain to $0.46 \mu \mathrm{g} / \mathrm{g}$ in hair, while concentrations in the organs of healthy people from Japan (who generally consume relatively high amounts of seafood) range from $0.02 \mu \mathrm{g} / \mathrm{g}$ wet weight to $0.89 \mu \mathrm{g} / \mathrm{g}$ in nails (24). In fatal cases of arsenic poisoning, the concentrations of arsenic in tissues changed and exceeded the above values, showing widespread distribution of arsenic in all organs, the highest levels (in decreasing order) were observed in liver, kidney, brain, lungs, heart, pancreas, spleen, and muscles (25). However, comparative studies of trace elements and heavy metals in cardiovascular tissues are yet difficult due to the lack of "normal" values and arsenic speciation in human tissues is scarce $(26,27)$. Most studies of arsenic speciation have focused on water, plants and animal tissues, and human fluids (e.g. urine) and tissues such as hair and nails $(28,29)$.

In autopsy samples of people exposed to environmental basal arsenic levels, the concentration of the element is very similar in all internal organs $\left(0.1 \mu \mathrm{g} \mathrm{g}^{-1}\right)$ but slightly higher in hair $\left(0.6 \mu \mathrm{g} \mathrm{g}^{-1}\right)$ and nails $\left(0.4 \mu \mathrm{g} \mathrm{g}^{-1}\right)$. However after an acute lethal dose $\left(8.0 \mathrm{~g}\right.$ of $\left.\mathrm{As}_{2} \mathrm{O}_{3}\right)$, the highest levels were observed decreasing order in liver, kidney and other organs (muscle, lungs, brain). The inorganic trivalent species was predominant $(>80 \%)$ and the metabolites MMA and DMA represented 10 and 5\% respectively except in lipid rich organs that concentrations of these species are higher (20). In animals arsenate has been shown to incorporate in the skeleton due to its similarity with phosphate anions. Background levels in breast milk range between 0.1 and 1 ng $\mathrm{L}^{-1}$, but concentrations multiplied by a factor of 4 have been observed in human in case of regular seafood consumption (30) and by a factor of 8 in case of consumption of drinking water containing $200 \mu \mathrm{g} \mathrm{As} \mathrm{L}^{-1}$ (15). Other data indicates that arsenic can easily crosses the animal and human placentas (29).

The present study deals the distribution of the total arsenic concentration in cardiovascular tissues, obtained by heart surgery of a group of heart patients subjected to chronic arsenic exposure of the Antofagasta region, and in the same cardiovascular tissues from a control group of patients subjected to the same surgery type of regions of Chile without arsenic exposure coming from drinking water. The cardiovascular tissues were auricle (AU), mammary artery (MAM), saphenous vein (SAP) and the pooled fat sample from these cardiovascular tissues (FAT). Also, we report the results of arsenic speciation in the cardiovascular tissues and main inorganic and organoarsenic species found in three heart tissues (AU,MAM and FAT) and the SAP (used as bypass) of people chronically exposed to arsenic in the Chilean II Region, suffering cardiovascular diseases (CVD) and subjected to hearth surgery in Antofagasta. The found concentrations of total As and As species, and the histology study of some of these tissues, contribute to a best understanding about if As or its main species could be involved in the heart disease.

For some geological areas of the planet, the adverse effects of arsenic exposure on human beings are a truth public health problem (31), that which also involve to the Medical Geology. Medical Geology is the science that deals with the impact of geologic materials and processes on animal and human health (32-34). 
International Journal of Science and Research (IJSR)

ISSN (Online): 2319-7064

Index Copernicus Value (2016): 79.57 | Impact Factor (2015): 6.391

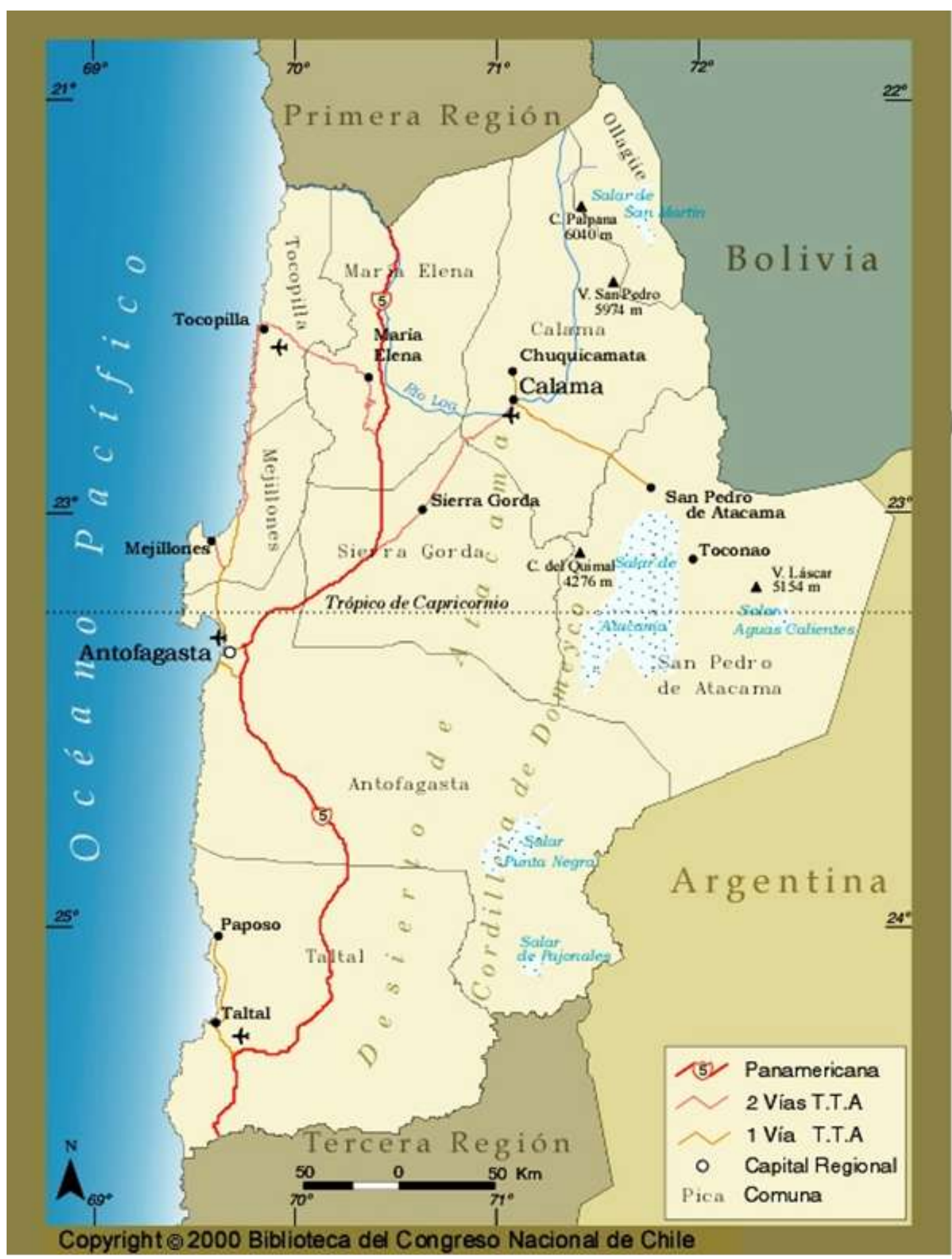

Figure 1: Region of Antofagasta in northern Chile

\section{Experimental}

This work was carried out according to the Helsinki IIdeclaration, with the consent and authorization of theAntofagasta Clinic. It was approved by the Committeeof Ethics of the University of Antofagasta (CBICREV $1 /$ 2010).

\subsection{Instrumentation and chromatographic materials}

Atomic absorption measurements were performed on a GBC 909 PBT Atomic Absorption Spectrometer coupled with a GBC HG-3000 Hydride Generator equipped with an electrothermal mantle GBC EHG-3000 to determine the total As content in the Chilean samples. A arsenic hollow cathode boosted discharge lamp (BDL) from Photron was used.

The Inductively Coupled Plasma Mass Spectrometer (ICPMS) used for the determination of total As concentrations in samples from persons living in Madrid, and as a detector after HPLC species separation, was an HP - 4500 (Yokogawa Analytical System, Tokio, Japan). This system was fitted with coof a Babington glass nebulizer and a Scott double pass spray chamber. Single ion monitoring at $\mathrm{m} / \mathrm{z} 75$ was used to collect the data. All signal quantification was performed in the peak area mode.

Volume 6 Issue 12, December 2017

\section{www.ijsr.net}

Licensed Under Creative Commons Attribution CC BY 


\section{International Journal of Science and Research (IJSR) \\ ISSN (Online): 2319-7064}

Index Copernicus Value (2016): 79.57 | Impact Factor (2015): 6.391

A PRP-X100 analytical and guard anion-exchange column (Hamilton, Reno, NV, USA) were used for HPLC-ICP-MS analysis. The column effluent was directly introduced into the nebulizer via a $250 \mathrm{~mm} \quad \mathrm{x} \quad 0.5 \quad \mathrm{~mm} \quad$ (id) polytetrafluoroethylene capillary tube.

For chromatographic separations, a HPLC system (LDC Division, Riviera Beach, Florida, USA) was used as a sample pump. Air was removed from the buffers by argon degassing for $15 \mathrm{~min}$ and the buffer was filtered prior to injection. $100 \mu \mathrm{L}$ of samples were introduced through a 0.45 $\mu \mathrm{m}$ nylon syringe filter into the injection valve Rheodyne 9125 (USA). TABLE 1 shows the optimized instrumental parameters for HG-AAS, ICP-MS and HPLC system.

Table 1: Instrumental parameters for total As determination and As speciation analysis.

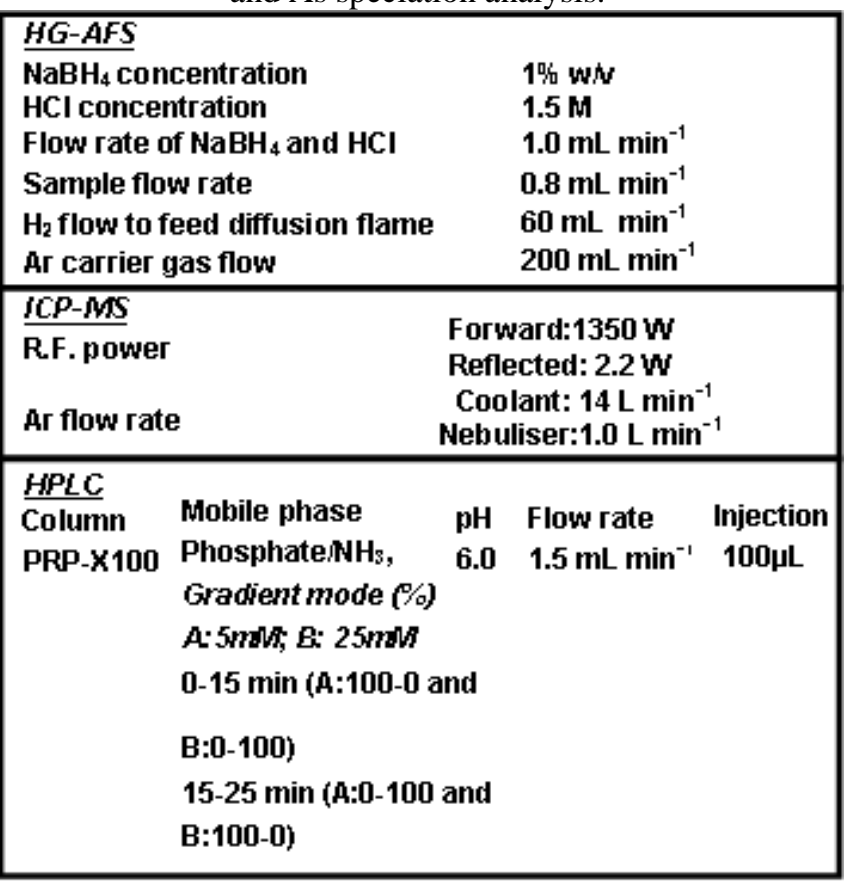

\subsection{Materials, reagents and standards}

Sample mineralization were carried out in Teflon reactor bombs placed in usual lab oven and in heating aluminium plate by means a two steps procedure like similar way as Welz and Melcher (35).

Solvent evaporation of extracts was performed in a Univapo100H-Unijet II system (UNIEQUIP, USA). Sonication of samples was performed in a focused ultrasonicbath (Bandelin Sonopuls HD-2200, Fungilab S.A., USA).

The extracting mixtures were prepared from deionised water (Milli-Q Ultrapure water systems, Millipore, USA) and HPLC-grade methanol (Merck, Darmstadt, Germany). Highpurity nitric and hydrochloric acids were obtained by the sub-boiling distillation of the analytical-grade reagent (Merck) in an I.R. distiller (Berghof, BSB-939IR, Germany).

$\mathrm{HF}, \mathrm{HNO}_{3}$ and $\mathrm{H}_{2} \mathrm{SO}_{4}$ acids were Suprapur grade (Merck); $\mathrm{HClO}_{4}$ and $\mathrm{Na}_{2} \mathrm{~S}_{2} \mathrm{O}_{8}$ were Instra grade (J. T. Baker). Other reagents such as $\mathrm{NaBH}_{4}, \mathrm{H}_{2} \mathrm{SO}_{4}, \mathrm{NaOH},\left(\mathrm{NH}_{4}\right) \mathrm{H}_{2} \mathrm{PO}_{4}$,
$\mathrm{H}_{3} \mathrm{PO}_{4}$, were obtained from Merck. Each arsenic species stock solution containing $1,000 \mathrm{~g} \mathrm{~L}^{-1}$ of As, was prepared by dissolving the respective amount of the pure compounds in water. $\mathrm{As}(\mathrm{III})$ and $\mathrm{As}(\mathrm{V})$ standards were prepared from sodium arsenite and sodium arsenate (Sigma Aldrich, St Quintin, Fallavier, France), dimethylarsinic acid (DMA) and methylarsonic acid (MMA) obtained from Merck, and arsenobetaine $(\mathrm{AsB})$ and arsenocholine $(\mathrm{AsC})$ obtained from Tri Chemical Laboratory Inc. (Japan). The stock solutions were kept at $4^{\circ} \mathrm{C}$ in the dark. Working solutions were prepared daily and then diluted with water to the final concentration. Three certified from National Research Council Canada (NRCC) reference materials: Luts-1 (no defatted Lobster hepatopancreas), Dorm-1 (Dogfish muscle) and Tort-1 (Lobster hepatopancreas) were used to validate the total As determination and also for As species characterisation.

\subsection{Sample populations}

Auricle( AU) tissue, saphenous vein (SAP), mammary artery (MAM) and heart fat tissues (FAT) from about 40 patients operated in the Antofagasta Clinic of coronary thrombosis were analysed for total As content. The samples were obtained from a population under study, made up of patients who have lived at least five years in the II Region of Chile, and population control samples were obtained from about 20 patients operated in the Catholic University Clinic in Santiago of Chile, which coming from Chilean Regions without arsenic problem.

All manipulations and procedures for the preparation of the samples were made in the bench of the "clean laboratory" inside a laminar flow hood (Labconco, Purifer Class II) using inert devices such as plastic and Titanium knives, agate grinding mortar, and scalpels, scissors and forceps of surgical stainless steel. In each case, then of be liberated of the Titanium clasp and the fats residues, the tissues were rinsed with deionised water and separated as single samples, except the fat of which was prepared as pooled sample. All samples were stored at $-20^{\circ} \mathrm{C}$ before uses. Dry weight / wet weight factors were obtained according UNEP protocol (36) at $60^{\circ} \mathrm{C}$.

From these samples, three different groups have been chosen for the study, results presentation and discussion: Group I. More contaminated group formed by 20 people presenting the higher Arsenic content in the auricle (the tissue with higher mean As level). Group II. Comparison group formed by 20 people presenting the lower As content in the auricle (probably the heart problem is not due to As); and Group III. Control group formed by 20 people suffering heart attack, which coming from V, VIII and IX Chilean Regions which are not exposed to the impact of arsenic (Valparaiso, Concepción and Temuco). Group IV. An additional samples from similar heart tissues were obtained for basal level from died persons living in Madrid where As contamination is not expected. Before operation, all the Chilean people initially analysed, filled in a survey with some personal characteristics for later relation with the As content TABLE 2.Patients had surgery for heart artery thrombosis; each patient was asked to complete a questionnaire table 3 . 
International Journal of Science and Research (IJSR)

ISSN (Online): 2319-7064

Index Copernicus Value (2016): 79.57 | Impact Factor (2015): 6.391

Table 2: Global characteristics of people under study

\begin{tabular}{|c|c|c|c|c|}
\hline Population & Region & Type of work & Age (years) & As stigma \\
\hline $\begin{array}{c}20 \\
\text { High As content }\end{array}$ & $\begin{array}{c}100 \% \\
\text { Region II. }\end{array}$ & $\begin{array}{c}\text { Mine: } 55 \% \\
\text { Industry: } 40 \% \\
\text { Others : } 5 \%\end{array}$ & 57.2 (mean) & $100 \%$ Yes \\
\hline $\begin{array}{c}15 \\
\text { Low As content }\end{array}$ & $\begin{array}{c}100 \% \\
\text { Region II }\end{array}$ & $\begin{array}{c}\text { Industry: } 30 \% \\
\text { Social: } 70 \%\end{array}$ & 56.3 (mean) & $100 \%$ No \\
\hline $\begin{array}{c}10 \\
\text { Control Group }\end{array}$ & $\begin{array}{c}100 \% \\
\text { Valparaiso } \\
\text { Concepcion } \\
\text { Temuco } \\
\text { V,VIII,IX Regions }\end{array}$ & $\begin{array}{c}\text { Social: } 60 \% \\
\text { Agriculture: } 40 \%\end{array}$ & 66.0 (mean) & $100 \%, \mathrm{No}$ \\
\hline
\end{tabular}

Table 3: Demographic questionnaire data (a) for the arsenic exposure Group I - II and non-exposure cardiac patients Group III

\begin{tabular}{|c|c|c|}
\hline & $\begin{array}{c}\text { As exposure } \\
\text { Group I and II }\end{array}$ & $\begin{array}{c}\text { As control } \\
\text { Group III }\end{array}$ \\
\hline Cardiac patients & 40 & 20 \\
\hline Age & & \\
Mean & 57 & 60 \\
Median & 56 & 59 \\
Min-Max & $33-78$ & $38-78$ \\
\hline Variables influenced by & As exposure & As control \\
medical geology factors & group, $\%$ & group, $\%$ \\
\hline BA & 72.1 & - \\
NBA & 21.9 & - \\
CN & 29.3 & - \\
RS & 25.1 & - \\
OC & 40.0 & - \\
WA & 47.9 & - \\
WCh & 22.8 & - \\
OW & 12.1 & - \\
NMW & 13.5 & - \\
\hline Conditional variables & As exposure & As control \\
& group, $\%$ & group, $\%$ \\
\hline S & 64.7 & 60.0 \\
NS & 31.2 & 40.0 \\
W & 46.0 & 56.0 \\
NW & 48.4 & 44.0 \\
L & 18.6 & - \\
NL & 77.7 & 100 \\
D & 73.5 & 32.0 \\
WD & 20.9 & 68.0 \\
F & 14.0 & 16.0 \\
M & 81.4 & 84.0 \\
\hline
\end{tabular}

(BA) patients born in the Antofagasta region and who have always resided in this region; (NBA) patients not born in the Antofagasta region, but who have lived there at least 5 years; $(\mathbf{C N})$ inhabitants patients of the centre-north zone of Antofagasta city; (RS) patients living in the south zone of Antofagasta city; (OC) patients of other cities of the Antofagasta region; (WA) patients that worked in Antofagasta city; (WCh) patients that worked in the mines of Chuquicamata; (OW) patients that worked in other copper mining locations, thermoelectric power plants and saltpeter mining; (NMW) patients that worked in different roles to mining and power generation; (S) patients who smoked; (NS) patients who did not smoke; (W) patients who consumed wine moderately; (NW) patients who did not consume wine; (L) patients with leucomelanosis; (NL) patients without leucomelanosis; (D) dislipidemic patients; (WD) patients without dislipidemia; (M) male patients; (F) female patients

\subsection{Mineralization for total arsenic determination}

About $0.5-1.0 \mathrm{~g}$ of agate mortar grinded sample were placed in a Teflon reactor bomb, $10 \mathrm{~mL}$ of concentrated $\mathrm{HNO}_{3}, 2 \mathrm{~mL}$ of concentrated $\mathrm{HClO}_{4}$ and $2 \mathrm{~mL}$ of $2 \% \mathrm{~m} / \mathrm{v}$ $\mathrm{Na}_{2} \mathrm{~S}_{2} \mathrm{O}_{8}$ were added, and the sample was pre-digested overnight at room temperature. Next, the reactor was heated to $150^{\circ} \mathrm{C}$ for 2 hours in an oven. After cooling, $0.5 \mathrm{~mL}$ of concentrated $\mathrm{H}_{2} \mathrm{SO}_{4}$ was added and the digested sample was heated in the heating aluminium plate by semi refluxing in a $50 \mathrm{~mL}$ glass Erlenmeyer flask for about 2 hours (ambient to $300^{\circ} \mathrm{C}$ ) until the final volume was about $2 \mathrm{~mL}$. The digested sample was diluted to $10 \mathrm{~mL}$ with $0.5 \mathrm{M} \mathrm{HCl}$ and total As was determined by HG-AAS. When analysis was performed by ICP-MS, distilled water was used for making up to the chosen volumes.

\subsection{Extraction for arsenic species}

About $0.5-1.0 \mathrm{~g}$ of the $60^{\circ} \mathrm{C}$ dried tissue materials were placed in plastic centrifuge tubes, and $10 \mathrm{~mL}$ of the methanol-water 1:1 v/v mixture was added following similar treatment that performed by Shibata and Morita (37). The mixture was mechanical shaken for 3 hours, maintained at $55^{\circ} \mathrm{C}$ for 10 hours and finally left in an ultrasonic focalized bath for $5 \mathrm{~min}$. The samples were centrifuged for $15 \mathrm{~min}$ at $6000 \mathrm{rpm}$. After centrifugation, the extract was removed using a Pasteur pipette and the residue was re-extracted using $5 \mathrm{~mL}$ of the same methanol-water mixture under the same operational conditions. The extraction procedure was repeated in the residue once again with a methanol - water mixture 9:1 v/v following the procedure formerly described. The methanol - water 1:1 and 9:1 extracts were separately submitted to rotary evaporator at $40^{\circ} \mathrm{C}$ under reduced pressure and a flow of extra pure $\mathrm{N}_{2}$. Each residue were dissolved in adequacy deionised filtered water volumes $(0.45 \mu \mathrm{m})$, and kept frozen $\left(-20^{\circ} \mathrm{C}\right)$ prior analysis. Two extracts were prepared from each sample and three for each reference materials.

\subsection{Determination of total As}

Total As content from Chilean people was measured in the samples, extracts and residues (after methanol - water extractions) after mineralization by HG-AAS. The arsenic content in the samples from Madrid (basal level), was measured by ICP-MS. Internal standard addition calibration was used for HG-AAS. External calibration using As(V) standard solution for ICP-MS was used. ${ }^{72} \mathrm{Ge}$ was used as an internal standard for ICP-MS. 


\section{International Journal of Science and Research (IJSR) \\ ISSN (Online): 2319-7064 \\ Index Copernicus Value (2016): 79.57 | Impact Factor (2015): 6.391}

\subsection{HPLC - ICP - MS for measurement of arsenic speciation}

The extracts were diluted with diluted mobile phase solution depending species concentration. $100 \mu \mathrm{L}$ of the diluted extracts were applied to the column. The ion intensities at $\mathrm{m} / \mathrm{z} 75$ were monitored. During ICP-MS analysis, an important interference is the possible formation of ${ }^{40} \mathrm{Ar}^{35} \mathrm{Cl}$. However, the concentration of chloride in the analysed extract is low and corrected by the instrument. The peaks were integrated using either ICP-MS Plasma Lab software or Grams/32 software (Galactic Industries, SalemNY, USA).

An injection of $100 \mu \mathrm{L}$ of $5.0 \mathrm{ng} \mathrm{mL} \mathrm{mL}^{-1}$ of $\mathrm{As}(\mathrm{V})$ before each chromatographic run were used apart the internal standard in order to correct any drift in the ICP-MS response.

\subsection{Analytical validation, quality control and traceability of arsenic measurements}

TABLE 4 summarizes the analytic validation data to prove the suitability and efficiency of the described techniques for the determination of arsenic in cardiovascular tissues; i.e. total arsenic, total extracted arsenic with methanol-water 1:1 and 9:1 and the arsenic recovery experiments from the standard reference materials spiked with arsenic species frequently found in biological tissues, such as primary standard of $\mathrm{As}^{3+}$ and $\mathrm{As}^{5+}$ of sodium arsenite and sodium arsenate (Sigma Aldrich, St Quintin, Fallavier, France); DMA (Merck); monometilarsonic acid (MMA) (Chem Service, USA); AsB and arsenocholine (AsC) (Tri Chemical Laboratory Inc. Japan). The SRMs used in these quality control approaches were DORM-1, DORM-2, TORT-1 and LUTS-1 (National Research Council, Division of Chemistry,Ottawa, Canada). Detection limits were calculated in accordance with IUPAC criteria $(38,39)$. The results of the measured values of arsenic were accepted if the coefficient variation of the precision and accuracy tests were less to $15 \%$ of the accepted or certified values, respectively.

Before being applied to the cardiovascular tissue samples, the arsenic speciation protocol was applied to samples of standard reference materials. Table 4: These results are very similar to those in other reports $(40-42)$.

Table 4: Quality control and traceability of the total As concentrations, $\mathrm{MeOH}-\mathrm{H}_{2} \mathrm{O}$ 1:1 fractionated arsenic concentrations and speciated concentrations of arsenic using standard Reference materials (SRM).

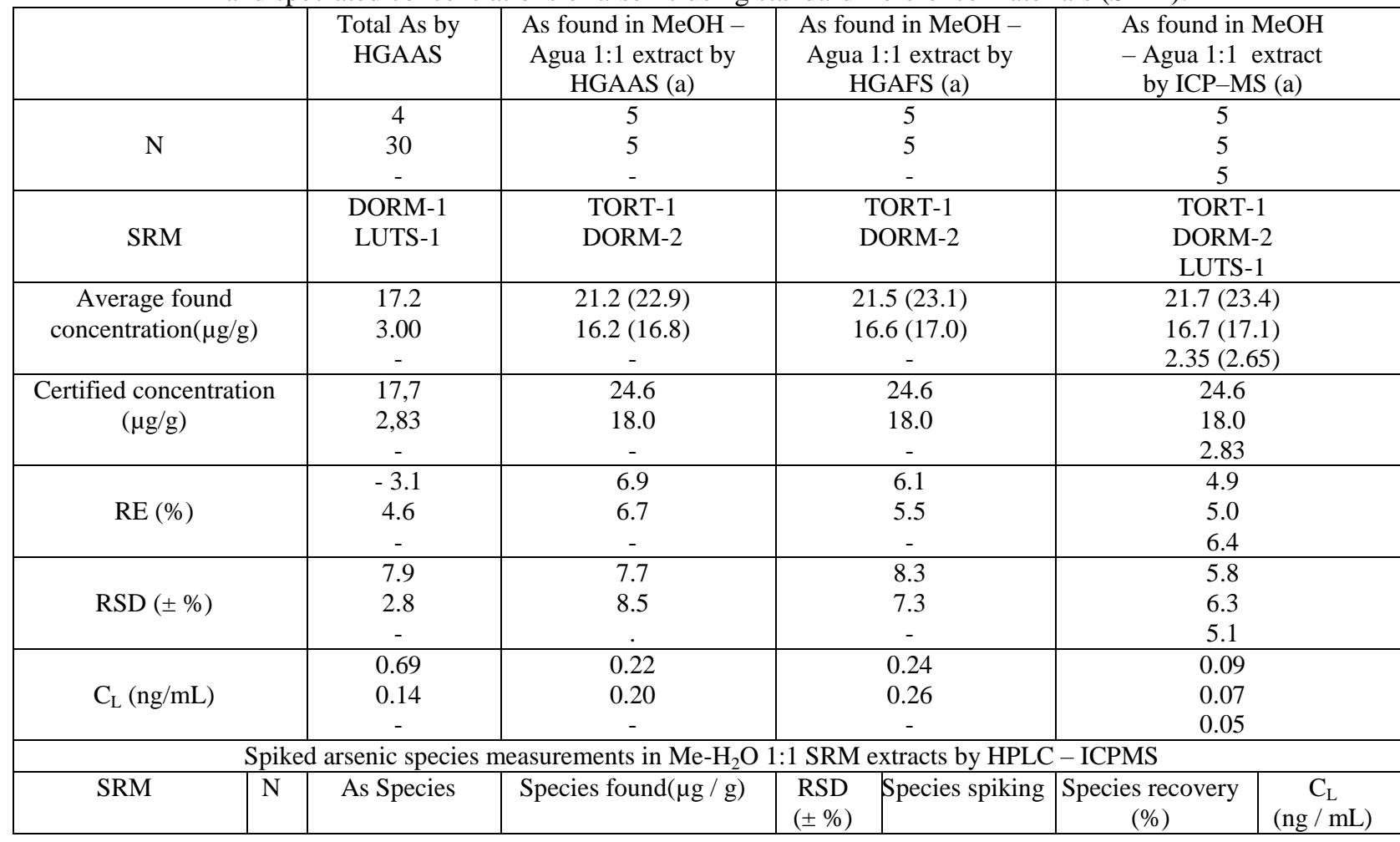

Volume 6 Issue 12, December 2017 www.ijsr.net 
International Journal of Science and Research (IJSR)

ISSN (Online): 2319-7064

Index Copernicus Value (2016): 79.57 | Impact Factor (2015): 6.391

\begin{tabular}{|c|c|c|c|c|c|c|c|}
\hline TORT -1 & 3 & $\begin{array}{c}\mathrm{As}^{3+} \\
\mathrm{As}^{5+} \\
\text { MMA } \\
\text { DMA } \\
\text { AsB }\end{array}$ & $\begin{array}{c}\mathrm{Nd} \\
0.33 \\
\mathrm{Nd} \\
2.04 \\
17.0\end{array}$ & $\begin{array}{c}- \\
0.09 \\
- \\
0.9 \\
1.7\end{array}$ & $50 \mathrm{ng} / \mathrm{mL}$ & $\begin{array}{l}98.6 \\
96.5 \\
96.9 \\
98.3 \\
95.1\end{array}$ & $\begin{array}{l}0.02 \\
0.03 \\
0.06 \\
0.05 \\
0.03\end{array}$ \\
\hline LUTS - 1 & 3 & $\begin{array}{c}\mathrm{As}^{3+} \\
\mathrm{As}^{5+} \\
\mathrm{MMA} \\
\text { DMA } \\
\mathrm{AsB}\end{array}$ & $\begin{array}{l}\mathrm{Nd} \\
\mathrm{Nd} \\
\mathrm{Nd} \\
0.15 \\
1.81\end{array}$ & $\begin{array}{c}- \\
- \\
- \\
0.07 \\
0.6\end{array}$ & $50 \mathrm{ng} / \mathrm{mL}$ & $\begin{array}{l}97.2 \\
95.7 \\
96.5 \\
98.5 \\
95.3\end{array}$ & $\begin{array}{l}0.02 \\
0.03 \\
0.06 \\
0.05 \\
0.03\end{array}$ \\
\hline DORM - 2 & 3 & $\begin{array}{c}\mathrm{As}^{3+} \\
\mathrm{As}^{5+} \\
\mathrm{MMA} \\
\mathrm{DMA} \\
\mathrm{AsB}\end{array}$ & $\begin{array}{c}\mathrm{Nd} \\
\mathrm{Nd} \\
\mathrm{Nd} \\
0.66 \\
15.1\end{array}$ & $\begin{array}{c}- \\
- \\
- \\
0.09 \\
0.8\end{array}$ & $50 \mathrm{ng} / \mathrm{mL}$ & $\begin{array}{l}96.6 \\
95.4 \\
96.9 \\
98.9 \\
95.1\end{array}$ & $\begin{array}{l}0.02 \\
0.03 \\
0.06 \\
0.05 \\
0.03\end{array}$ \\
\hline
\end{tabular}

\subsection{Statistics}

Statistical analyses were carried out using the statistical package STATISTICA 6.1 (StatSoft, Tulsa, OK); $<<0.05$ was considered statistically significant.

\subsection{Histological treatment}

For the histological study performed in some samples, the tissue was washed for 24 hours in running water and fixed in paraffin blocks dyed with hematoxilin-eosine, trichromic of Masson and orceine Van Giesson (43). The histochemical methods it's based on combination of chromogenic reagents with mixtures of masking agents that block the reactivity of tissues. The paraffinzed sections show green granules, insoluble in water, through dissolved by acid and by ammonium hydroxide. This procedure demonstrates pretty well every practical histopathologic with additional diagnostic studies such as histological examination in microscopic scission.

\section{Results and Discussion}

\subsection{Total As content}

The interval and mean value for total As found in the samples of the four analysed groups are given in TABLE 5. In the Group I (more contaminated), the AU has by far the higher concentration, with a mean value of $7.7 \mu \mathrm{g} \mathrm{g}^{-1}$, dry tissue, following by the SAP with $2.5 \mu \mathrm{g} \mathrm{g}^{-1}$. MAM and FAT tissues in this group present similar but lower As concentration than the former tissues with about $1 \mu \mathrm{g} \mathrm{g}^{-1}$ each. The total As concentrations found in the auricle (and also saphene) of some people, not chosen as components of the Group I, are really high of about $20 \mu \mathrm{g} \mathrm{g}^{-1}$ that reveal the high impact of the As in some individuals living and working in the contaminated areas. The comparison between Group II (less As contaminated in the Region) and Group III, (people from V, VIII an IX Chilean Regions), shows that concentration in the different tissues are quite similar. Considering the long distance between both population groups, these values can be considered as the mean level in these tissues for Chilean people.
Table 5: Concentration intervals and mean value for total As in the analysed tissues for the different analysed groups

\begin{tabular}{|c|c|c|c|c|}
\hline Tissue & $\begin{array}{l}\text { Group I. } \\
\text { (High } \\
\text { Ascontent) } \\
\end{array}$ & \begin{tabular}{|l} 
Group II. \\
(Low As \\
content) \\
\end{tabular} & $\begin{array}{c}\text { GroupIII. } \\
\text { (Control } \\
\text { group) }\end{array}$ & $\begin{array}{c}\text { Group IV. } \\
\text { (Basal } \\
\text { group) } \\
\end{array}$ \\
\hline Auricle & \begin{tabular}{|c|}
$7.44-9.4$ \\
7.7 \\
\end{tabular} & $\begin{array}{c}0.79-1.22 \\
1.0\end{array}$ & $\begin{array}{c}0.5-1.2 \\
0.9\end{array}$ & $\begin{array}{c}32 \pm 2(\mathrm{ng} / \\
\mathrm{g})\end{array}$ \\
\hline Saphene vein & \begin{tabular}{|c|}
$1.1-7.7$ \\
2.5 \\
\end{tabular} & \begin{tabular}{|c|}
$0.26-1.8$ \\
0.9 \\
\end{tabular} & $\begin{array}{c}0.56-1.6 \\
1.0 \\
\end{array}$ & $\begin{array}{c}\text { (ventricule) } \\
44 \pm 3(\mathrm{ng} / \mathrm{g})\end{array}$ \\
\hline $\begin{array}{c}\text { Mammary } \\
\text { artery }\end{array}$ & \begin{tabular}{|c|}
$1.49-2.18$ \\
1.1 \\
\end{tabular} & \begin{tabular}{|c|}
$0.12-1.7$ \\
0.6 \\
\end{tabular} & $\begin{array}{c}0.32-1.2 \\
0.8 \\
\end{array}$ & \\
\hline Fat & $\begin{array}{c}0.40-3.1 \\
1.0 \\
\end{array}$ & $\begin{array}{c}0.37-1.6 \\
1.7 \\
\end{array}$ & $\begin{array}{c}0.47-1.5 \\
0.8\end{array}$ & \\
\hline
\end{tabular}

However they are quite high comparing the basal level of the whole heart tissue of about $0.003-0.026 \mu \mathrm{g} \mathrm{g}^{-1}(17)$ dry tissue and the Group IV of a person living in Madrid.

TABLE 6 shows the statistical results of the total concentrations of arsenic in the cardiovascular tissues of the Antofagasta region cardiac patients Group I, II and the control cardiac patients Group III. Application of the Shapiro-Wilkinson test shows that a normal $(p=0.05)$ distribution is not followed in either group; the distribution spreads are lognormal. FIGURE 2 shows the histograms of arsenic concentrations in AU and SAP in both groups of patients. Application of the student $\mathrm{t}$-test for independent groups $(\mathrm{p}=0.05)$ demonstrated that the arsenic concentrations in AU and MAM were significantly different between both groups of patients, but not for SAP and FAT. The highest arsenic concentrations in the cardiovascular tissues of the arsenic exposure Group I, II and non-exposure cardiac patient Groups III were found in AU and SAP, respectively, but the arsenic concentrations in the SAP of both groups of heart patients were not significantly different. 


\title{
International Journal of Science and Research (IJSR) \\ ISSN (Online): 2319-7064 \\ Index Copernicus Value (2016): 79.57 | Impact Factor (2015): 6.391
}

Table 6: Statistical parameters for the total arsenic concentrations in cardiovascular tissues of the arsenic exposure Group I,

II and non-exposure Group III. Concentrations in $\mu \mathrm{g} / \mathrm{g}$ dry weight.

\begin{tabular}{|l|c|c|c|c|c|}
\hline Cardiovascular tissues & $\mathrm{N}$ & Mean & SD $( \pm)$ & Min-Max & Median \\
\hline Auricle, As exposure Group I, II & 40 & 4.85 & 3.85 & $0.40-29.4$ & 3.79 \\
\hline Auricle, control group III & 20 & 2.56 & 2.51 & $0.52-9.75$ & 1.99 \\
\hline Mammary, As exposure groupI, II & 40 & 1.52 & 1.85 & $0.13-13.1$ & 0.90 \\
\hline Mammary, control group III & 20 & 0.56 & 0.27 & $0.20-1.35$ & 0.51 \\
\hline Saphenous, As exposure groupI, II & 40 & 2.97 & 2.95 & $0.11-23.8$ & 2.13 \\
\hline Saphenous, control group III & 20 & 3.79 & 3.89 & $0.38-15.6$ & 1.99 \\
\hline Fatty CV tissue, As exposure group I, II & 40 & 1.27 & 1.64 & $0.076-14.3$ & 0.78 \\
\hline Fatty CV tissue, control group III & 20 & 0.72 & 0.54 & $0.24-2.60$ & 0.51 \\
\hline
\end{tabular}

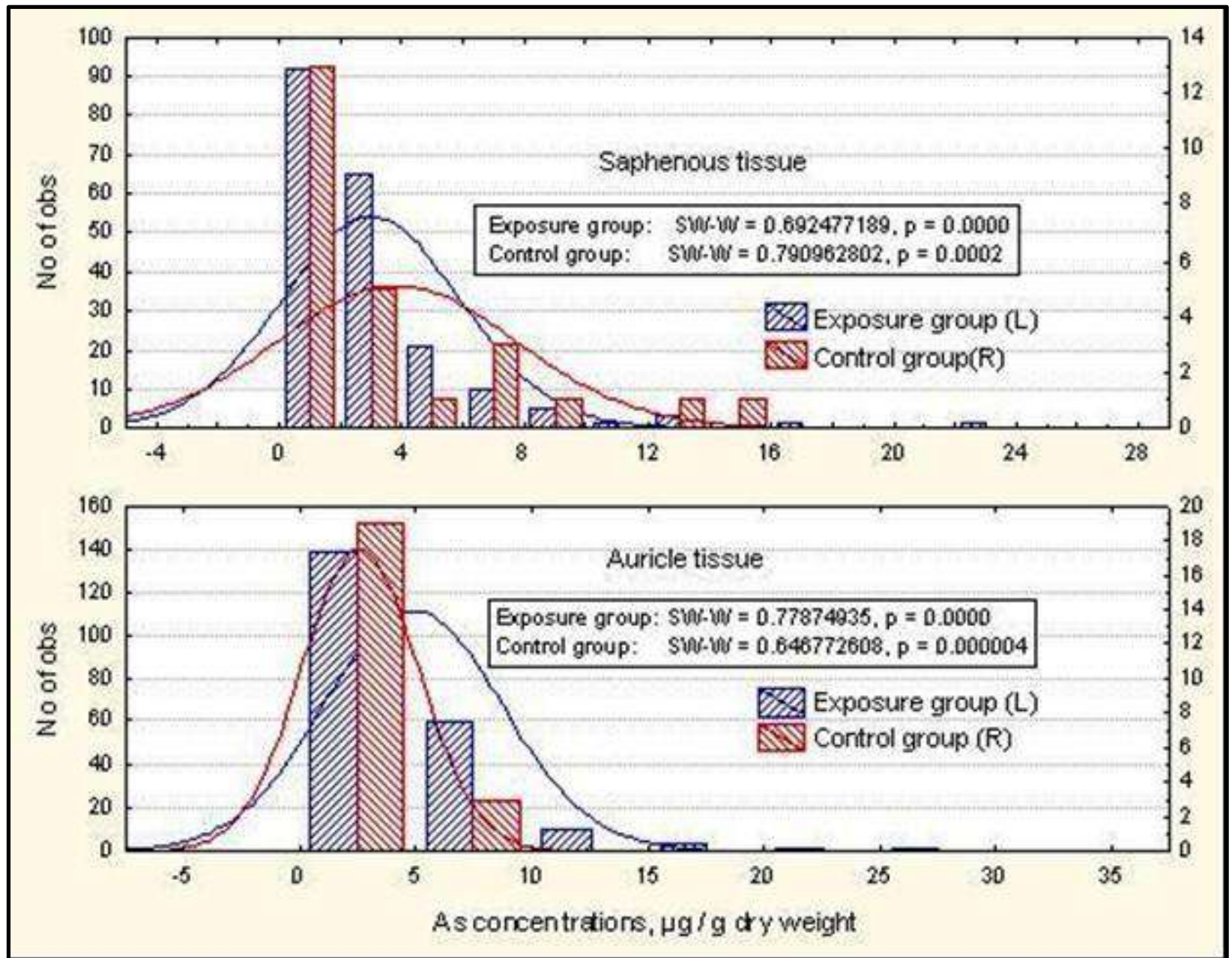

Figure 2: Histograms of total arsenic concentrations in saphenous vein and auricle tissues of cardiac patients from arsenic exposure Groups I, II and non-exposure Groups III

FIGURE 3 shows the ratio between mean values for the AU and the other tissues in the same population group. FIGURE 4 shows the ratio for the same tissue between the three
Chilean groups analysed. As we can see, Group I support the higher difference between the AU (and in less extend the SAP) and the other tissues.

\section{Volume 6 Issue 12, December 2017}

\author{
www.ijsr.net
}


International Journal of Science and Research (IJSR)

ISSN (Online): 2319-7064

Index Copernicus Value (2016): 79.57 | Impact Factor (2015): 6.391

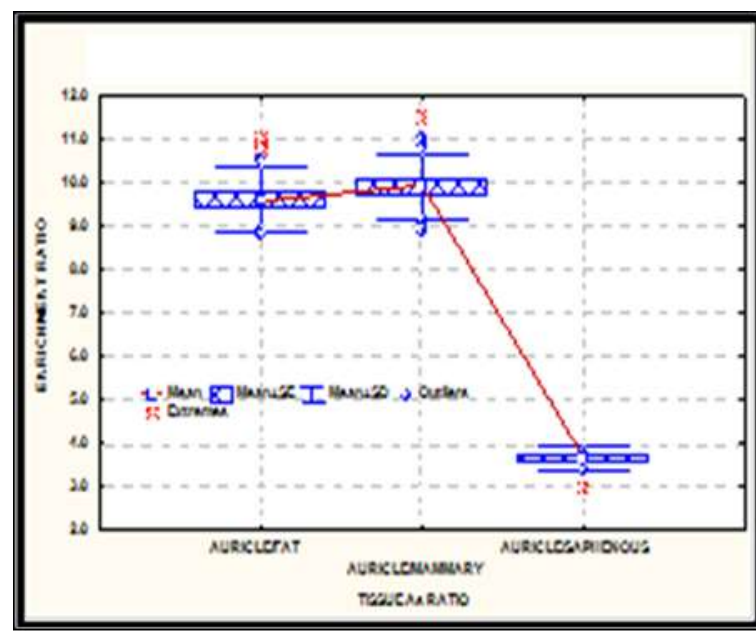

a) Group I

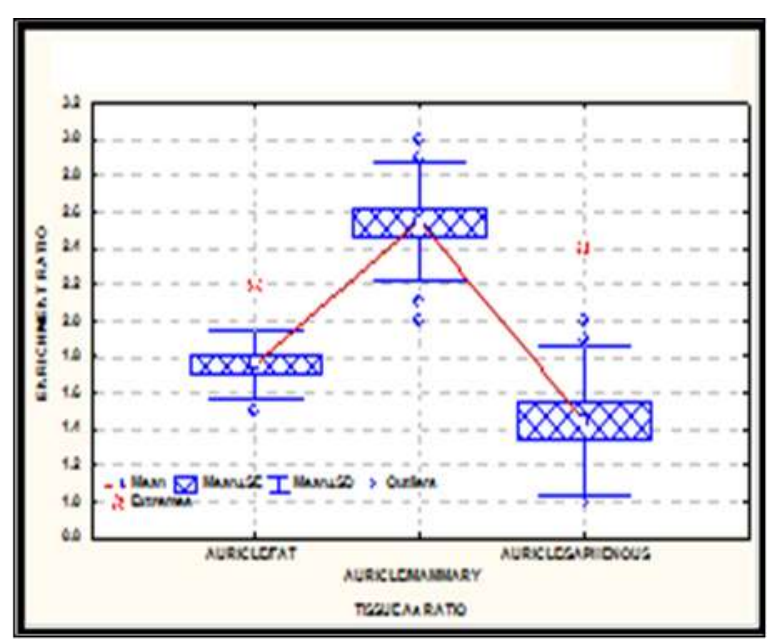

b) Group II

Figure 3: Total As relation between AU and SAP, MAM and FAT tissue in each of the considered Groups

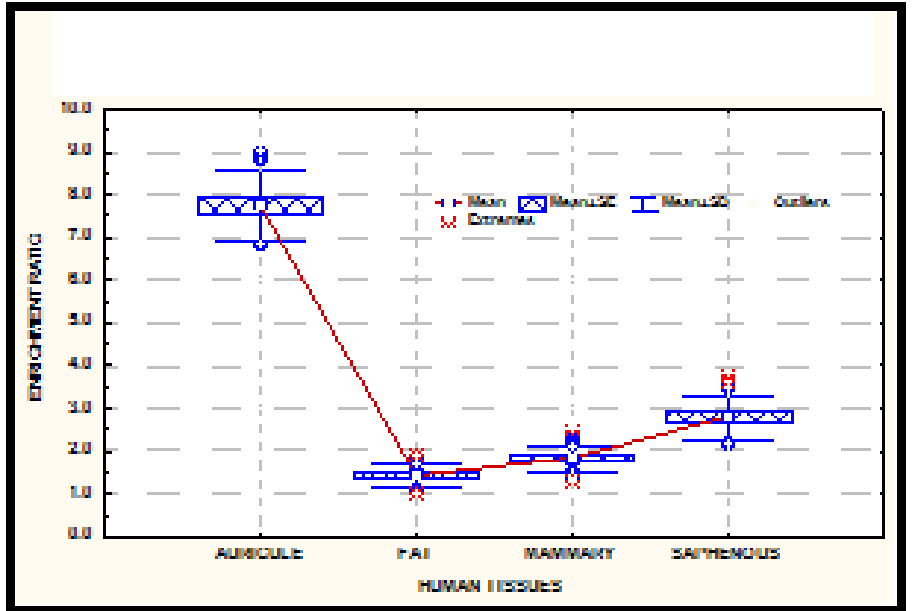

Figure 4: Total As relation between the same tissue (AU, SAP, MAM and FAT tissue) in each of the considered Groups I and II.

The total concentrations of arsenic in the cardiovascular tissues of patients of the arsenic exposure Group I and II were associated to the demographic questionnaire data, for which the variables described above were considered TABLE 3. The total arsenic concentrations in the cardiovascular tissues of control group patients were associated with conditional variables, i.e. patients who smoked $\left(\mathrm{S}_{\mathrm{c}}\right)$, patients who did not smoke $\left(\mathrm{NS}_{\mathrm{C}}\right)$; patients who consumed moderately wine $\left(\mathrm{W}_{\mathrm{c}}\right)$, patients who did not consume wine $\left(\mathrm{NW}_{\mathrm{c}}\right)$; patients with dislipidemia $\left(\mathrm{D}_{\mathrm{c}}\right)$, patients without dislipidemia $\left(\mathrm{WD}_{\mathrm{c}}\right)$; male patients $(\mathrm{M})$ and female patients $(\mathrm{F})$. When the arsenic concentrations are associated with the variables influenced by geomedical factors, the application of the student test to the arsenic concentrations in auricle (AU), mammary artery (MAM) and saphenous vein (SAP) of the exposed Group I and II to arsenic, demonstrated that significant differences do not exist among the arsenic concentrations inside oneself type of cardiovascular tissue.It can be inferred that the arsenic concentrations on the cardiovascular tissues of cardiac patients of the Antofagasta region are independent of where they live and work in the Antofagasta region. There were significant differences in the arsenic concentrations in the pooled FAT cardiovascular samples for several pairs of variables related to medical geology factors: $\mathrm{RS}$ vs $\mathrm{BA}, \mathrm{CN}$, OC, WCh, NMW, and WA vs NMW. RS correspond to patients with residence at the south zone of Antofagasta city, which is near to copper smelting facilities.

The associative linking among arsenic concentrations in the cardiovascular tissues of the arsenic exposure Group I, Group II and control Group III with conditional variables (TABLE 3$)$, allowed by means the student $\mathrm{t}$-test $(\mathrm{p}=0.05)$ to identify statistical difference between the arsenic concentrations in the cardiovascular tissue of both groups of cardiac patients. For AU, the differences were significant for the variables NS, NW, NL, D, and M; in MAM, the differences of arsenic concentration between both groups were significant for $\mathrm{W}, \mathrm{NL}, \mathrm{D}$ and $\mathrm{M}$; in $\mathrm{SAP}$, the differences in arsenic concentration between both groups were significant alone for $\mathrm{W}$ and $\mathrm{M}$. For FAT, they were not significant differences between the arsenic concentrations from the arsenic exposure Group I, II and control Group III. In this way, the box plots of the FIGURE 5 show the arsenic concentrations profiles in cardiovascular tissues translated according to the conditional variables of both groups. The plateau of the medians of the arsenic concentrations in $\mathrm{AU}$, MAM and FAT of the arsenic exposure group is approximately twofold major than the arsenic concentrations in the same tissues of the control Group III. In SAP of the control Group III, some cases presented median values for arsenic concentrations higher than that of the corresponding

\section{Volume 6 Issue 12, December 2017}

\section{www.ijsr.net}




\section{International Journal of Science and Research (IJSR) \\ ISSN (Online): 2319-7064 \\ Index Copernicus Value (2016): 79.57 | Impact Factor (2015): 6.391}

cases of the arsenic exposure Group I and II. The above results permit infer that the influence of the medical geology factors are more determinative than conditional variables for the arsenic enrichment in cardiovascular tissues of humans; for another part, heart AU and MAMcould be good biomarker for arsenic exposure. Arterial vessels have already been proposed as biomarkers for the exposure to other heavy metals.
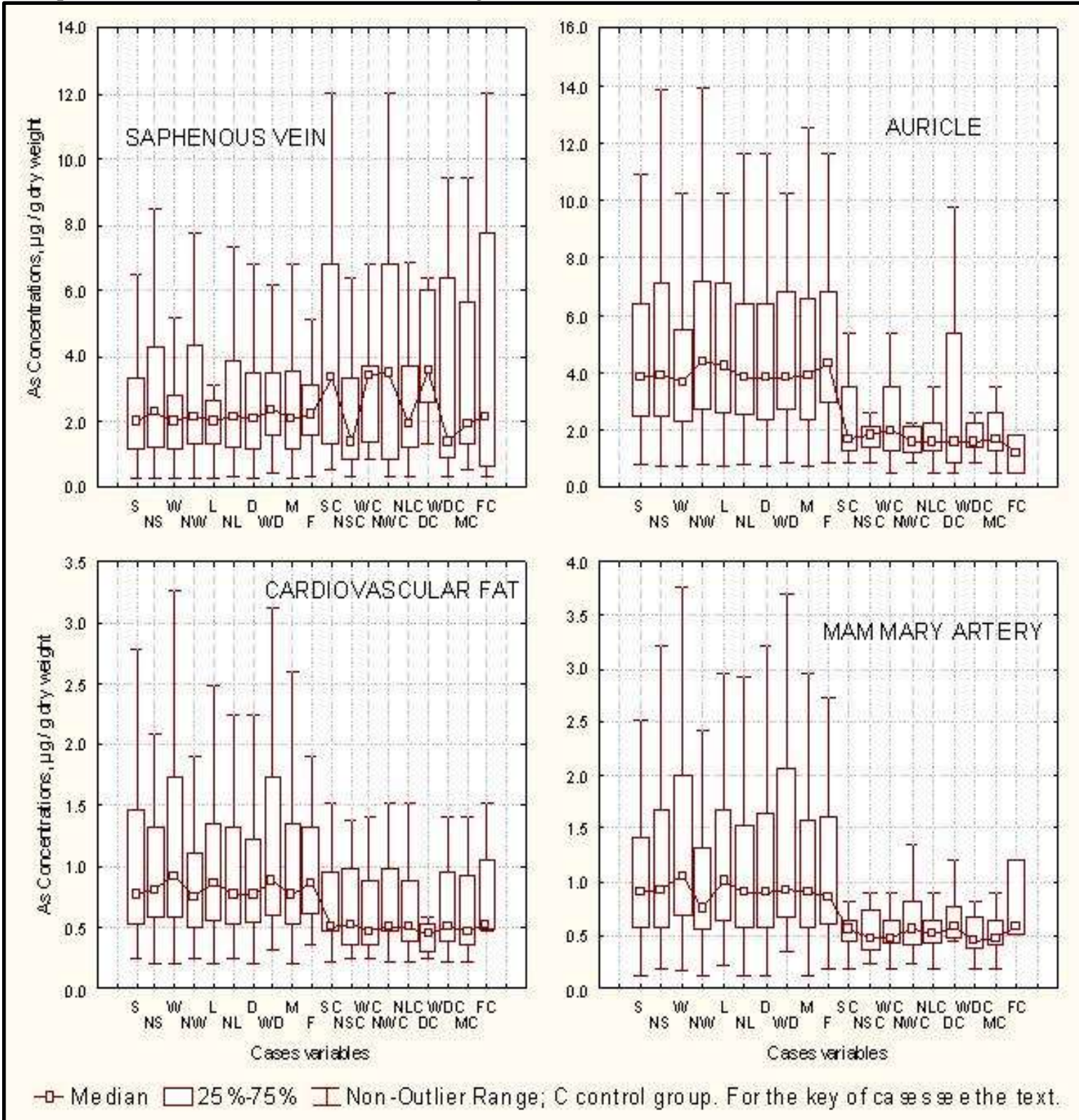

Figure 5: Box plots of the arsenic concentrations in cardiovascular tissues translated according to the demographic conditional case variables of the arsenic exposure and control cardiac patient groups.

\subsection{Histological study}

FIGURE6Aand6Bshows the histological plates for the saphenous of a damaged and non-damaged tissue respectively. The vascular pathology, FIGURE6A, is type concentric intimal fibrosis. This vein-damage consists in the expansion of the internal surface due to miofibroblastos and due to this expands; the light circumference is strongly reduced. In this case, the tissue is seriously ill and the intimal layer has analogous thickness than the muscular layer. The concentric intimal fibrosis does not belong to the principal atherosclerotic disease damage, main causes for heart attack and is produced by age, or by the influence of chemical or immunological processes. In our case, the person is relatively young (45 years old) and can be suspected of arsenic as the main cause of the tissue damage. Then, appear not to be apparent that arsenic may cause necrosis in cardiovascular tissues of the man(44). However, at the light of the new knowledge, a critical issue is how to distinguish between apoptosis and necrosis (45). The total As concentration found in the saphenous of this patient was of $2.1 \mu \mathrm{g} \mathrm{g}^{-1}$. 


\section{International Journal of Science and Research (IJSR)

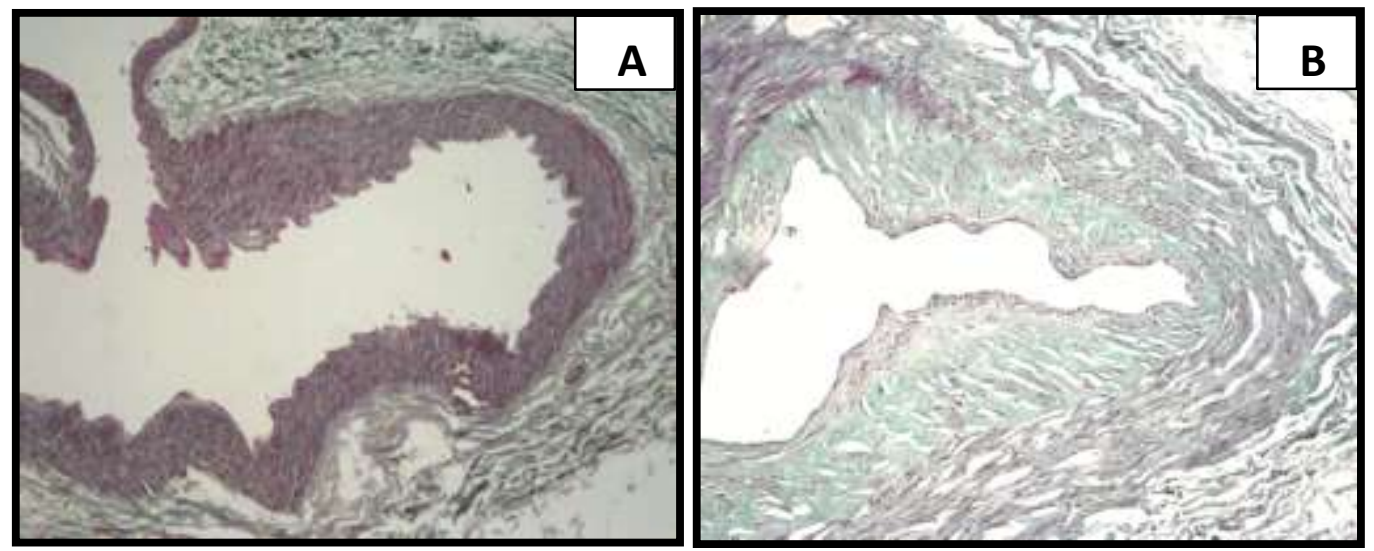

Figure 6: A) Histological study of a saphenous vein suffering concentrica intimal fibrosis taken from a cardiac patient of the As exposure group.B) Histological study of a normal saphenous vein from the As non- exposure group. Haematoxylin-Eosin $\times 40$

\subsection{Arsenic species found in cardiovascular tissues}

TABLE 7 shows the results of the arsenic fractionation in methanol-water mixtures (37) and the IC-HPLC-MS chromatographic speciation of the cardiovascular tissues of three heart arterial thrombosis patients of 37, 44 and 53 years old, who had lived in the Antofagasta region. These results show that most of the arsenic in the tissues examined was extracted by the 1:1 and 9:1 methanol-water-extracting solutions; this has also been observed in other biological tissues (37). Under these conditions, the arsenic species contained in these cells could be extracted and the arsenic speciation investigated. Most of the total arsenic concentrations were extracted in 1:1 methanol-waterextracting solution (TABLE 7), so we can assume that at least the 1:1 methanol-water extract contains the arsenic species of the cytosol solution.

Table 7: Fractionation and chromatographic speciation (HPLC-ICPMS) yielding of arsenic in cardiovascular tissues of cardiac patients of the arsenic exposure group from the region of Antofagasta at north of Chile.

\begin{tabular}{|c|c|c|c|c|}
\hline & Auricle & $\begin{array}{c}\text { Mammary } \\
\text { artery }\end{array}$ & $\begin{array}{c}\text { Saphenous } \\
\text { vein }\end{array}$ & Fat tissue \\
\hline Total As $(\mu \mathrm{g} / \mathrm{g})$ & $6.9 \pm 2.1$ & $0.9 \pm 0.2$ & $4.96 \pm 1.2$ & $0.8 \pm 0.2$ \\
\hline \multicolumn{5}{|c|}{ Fractionation and chromatographic arsenic speciation (a) } \\
\hline $\mathrm{MeOH}-\mathrm{H}_{2} \mathrm{O}$ & $70.9 \pm$ & $60.3 \pm 2.7$ & $56.2 \pm 2.9$ & $67.4 \pm 2.9$ \\
$(1: 1)$ & 3.1 & $\mathrm{Nd}$ & 30.1 & $\mathrm{Nd}$ \\
$\mathrm{As}^{3+}$ & 42.4 & 29.8 & 4.4 & 21.5 \\
$\mathrm{As}^{5+}$ & 6.8 & 3.8 & $\mathrm{Nd}$ & $\mathrm{Nd}$ \\
$\mathrm{MMA}$ & $\mathrm{Nd}$ & 6,2 & 3.1 & 5.8 \\
$\mathrm{DMA}$ & $\mathrm{Nd}$ & 18.8 & $\mathrm{Nd}$ & 33.9 \\
$\mathrm{AsB}$ & $\mathrm{Nd}$ & & & \\
\hline $\mathrm{MeOH}-\mathrm{H}_{2} \mathrm{O}$ & $19.3 \pm$ & $26.2 \pm 2.5$ & $29.7 \pm 2.9$ & $30.3 \pm 2.2$ \\
$(9: 1)$ & 2.0 & & & \\
\hline Residual As & $9.1 \pm 1.8$ & $12.0 \pm 1.1$ & $12.2 \pm 1.3$ & $1.9 \pm 0.7$ \\
\hline \multicolumn{5}{|c}{}
\end{tabular}

(a) Mean percentages (wet weight basis) of the tissues of three cardiac patients regarding their average total arsenic concentration; $\mathrm{Nd}=$ not detected.

The arsenic speciation protocol described in this work was applied separately to the AU, MAM, SAP and FAT of each of the three cardiac patients from the arsenic exposure group of the Antofagasta region, and of a cardiac patient of the arsenic non-exposure group who had lived in the Valparaíso region all of his life. The arsenic speciation results are shown in TABLE 7 show the HPLC-ICPMS arsenic chromatographic speciation profiles of $\mathrm{AU}$ and MAM cytosol of the cardiac patient with the highest arsenic enrichment.

The arsenic speciation results in the cardiovascular tissues studied in this work shows that only arsenite $\left(\mathrm{As}^{3+}\right)$ and arsenate $\left(\mathrm{As}^{5+}\right)$ species were found in the AU (TABLE 7). Both inorganic arsenic species were confirmed by spiking the standard solutions of the species; arsenite was also confirmed after being separated by means of cationic chromatography using the cationic column Hamilton PRP $X$ 200, in which $\mathrm{As}^{3+}$ does not overlap with other arsenic species. Arsenite was also the predominant species in SAP, which suggests that the arsenite species could be the main arsenic species in the cytosol of this tissue, but a small amount of DMA species were also found. In MAM, the major arsenic species were arsenate and AsB, DMA and MMA were only minor species; arsenite was not found. In the pooled fat of the cardiovascular tissues, AsB was the predominant species, followed by arsenate and DMA. The arsenic species stability was also monitored during sample preparation and storage (5).

MMA and DMA are the main products of the cellular biomethylation through the conjugated effects of $\mathrm{S}$ adenosylmethionine and the methyltransferase enzyme, but this work do not allow discrimination between As(III) and As $(V)$ methylated species. Hence, the spiking additions were made with $\mathrm{As}(\mathrm{V})$-methylated arsenicals. $\mathrm{As}(\mathrm{V})$ is the main arsenic species in natural waters enriched in arsenic, therefore the biotransformation of $\mathrm{As}(\mathrm{V})$ to $\mathrm{As}(\mathrm{III})$ must be a main mechanism in organisms. In general, MMA and DMA species have been considered important species in arsenic detoxification mechanisms, so it was surprising that DMA and MMA species were not detected in AU and the concentration of DMA was very low in the SAP and MAM (TABLE 7). Similar results were found in heart tissues of chickens (46). AsB is believed to have a very low toxicity and has been found in human serum (9); the presence of arsenobetaine was unexpected in this work; this organarsenical species enters human beings principally from marine foods and from agricultural products coming from 


\section{International Journal of Science and Research (IJSR) \\ ISSN (Online): 2319-7064}

Index Copernicus Value (2016): 79.57 | Impact Factor (2015): 6.391

polluted soils and/or watered with arsenic-enriched waters $(5,9)$.

In vivo methylation has long been proposed as an arsenic detoxification pathway for inorganic arsenic (22, 47, 48), but it has recently been shown that As(III)-MMA and As(III)DMA, two intermediates in arsenate methylation, are more toxic to cells than $\mathrm{As}^{3+}$ and $\mathrm{A}^{5+}$ ions $(22,47,49,50)$. Arsenic is primarily metabolized in the liver and cardiovascular tissue probably does not efficiently metabolize arsenic. The inefficiency of methylation mechanisms could be due to the lack of methylating agents in cardiovascular tissues. The methylation processes mainly occur in the liver and kidney of animals and is dependent on the type of animal; guinea pigs, marmosets, tamarind monkeys, chimpanzees, cannot methylate arsenic (51 - 54). Humans methylate arsenic(55, $56)$, but at a specific inorganic arsenic dose, the methylation efficiency decreases in animals and humans (55). A strong interaction of inorganic arsenic with cell constituents could lead to a larger fraction of stabilized inorganic arsenic (51).

Another response mechanism to the toxicity of $\mathrm{As}^{3+}$ could be its interaction with arsenic-binding proteins in the cytosol. Such arsenic-binding proteins in cardiovascular tissues have been found in arsenic-exposure patients (26); $\mathrm{As}^{3+}$ is the main species bound to proteins in an intracellular solution of rat liver in which was also found about one-half of the methylated arsenic species bound to proteins (57). Inorganic arsenic species have a high affinity for proteins containing conjugated sulphur groups and therefore extracellular and intracellular proteins could bind arsenic. The direct toxic effects of arsenic are thought to result from its interaction with sulfhydril groups in proteins $(58,59$,$) .$

We report, for the first time, the total concentrations of arsenic in cardiovascular tissues, obtained via heart surgery, from a group of arsenic-exposure cardiac patients who have lived in Antofagasta, an area of Chile with exposure to arsenic, in relation to a group of cardiac patients who have lived in regions of Chile without arsenic exposure. Arsenic speciation status was also investigated in the tissues of three patients subjected to heart surgery from the arsenic exposure group, and in a patient from the non-exposure group. Knowledge of total arsenic level concentrations and the speciated distribution of arsenic in cardiovascular tissues, in particular, the prevalence of $\mathrm{As}^{3+}$ in the auricle of the arsenic exposure group of heart artery thrombosis patients, will aid the understanding of the long-term effects of arsenic on cardiovascular and vascular illnesses. The results obtained in this work, supplemented with recent epidemiologic $(60,61)$ evidence, allow us to conclude that the cardiovascular tissues are good biomarker tissues of the risk to cardiovascular health of exposure to arsenic. In particular, it was demonstrated that the auricle is an "As ${ }^{3+}$ target tissue", which is important because inorganic As(III) is the most toxic arsenic species. After the first methanolic extraction which contain to the cytosol solution, the As(III) extracted was about $50 \%$ of the total As content in the tissue. The $\mathrm{As}(\mathrm{V})$ is about $10 \%$ of the total. This result is interesting because $\mathrm{As}(\mathrm{V})$ is the main contaminant species present in the natural waters, therefore biotranformation to As(III) is a main mechanism. No other species seems to be present.
In the saphenous vein also $\mathrm{As}(\mathrm{III})$ and $\mathrm{As}(\mathrm{V})$ are the main species present, but little amount of other species such as DMA was found. One again the As(III) is the predominant species in the methanolic extract, which could involve that free As(III) specie is a principal component of the cytosol solution in this cardiovascular tissues.

In fat tissue $\mathrm{AsB}$ is the predominant species and in the mammary artery the As(V) species, that account about $40 \%$ and $30 \%$ respectively of the total As content in the respective tissues.

\section{Conclusions}

The results of this work and recent epidemiologic knowledge $(16,17,62)$ allow concluding that the arsenic accumulation and their speciation in cardiovascular tissues, particularly in human beings subjected to chronic arsenic exposure, they are factors of risk fortheir heart health. In particular, the auricle (AU)behaves as an " $\mathrm{As}^{+3}$ ", target tissue, which is one of the most toxic arsenic species. Otherwise, linking of the total concentrations of arsenic with conditional variables and variables related to medical geology factors, allowed us to infer that the latter are more significant for the cardiovascular risk of arsenic exposure in the Antofagasta region.

One surprising fact is that the DMA and MMA species are absent in the auricle tissue and the concentration of DMA is very low in the saphenous vein in Group I, mostly considering that these species are the main species formed in the detoxification mechanism. Some explanation can be highlighted: i) the lack of methylation mechanisms because of the lack of methylating agents in these tissues; ii) at a certain inorganic As dose level, the methylation efficiency decreases in animals and humans (51); iii) the incapability of DMA to bind some cell constituents as in the case of lungs of rabbits has been found (52).

The presence of high total As and high As(III) species content in the auricle and saphenous of more contaminated people (Group I), the damage found in the saphenous tissue and the global characteristics of the people under study in which the As stigmas are present in all of them, suggests that As could be involved in the cardiovascular diseases (CVD).

\section{References}

[1] Román - Silva, D., Rivera L., Morales T., Ávila J., Cortés P. Determination of trace elements in environmental and biological samples using improved sample introduction in flame atomic absorption spectrometry (HHPN - AAS; HHPN - FF- AAS). Intern. J. Environ. Anal. Chem. 2003, 83, 327 - 41.

[2] Tchounwou, P. B., Yedjou, C. G., Patlolla, A. K., Sutton, D. J. Heavy Metals Toxicity and the Environment. NIH Public Access.2012, 10, 133-164.

[3] Marshall G., Ferreccio C., Yuan Y., Bates M.N., Steinmaus C., Selvin S.,Liaw J., Smith A.H.Fifty-year study of lung and bladder cancer mortality in Chile related to arsenic in drinking water. $\mathrm{J}$ Natl Cancer Inst 2007, 99, $920-928$. 


\section{International Journal of Science and Research (IJSR) \\ ISSN (Online): 2319-7064}

Index Copernicus Value (2016): 79.57 | Impact Factor (2015): 6.391

[4] Román D.A., Pizarro I,, Rivera L., Cámara C., Palacios M.A., Gómez M.M., Solar C. An approach to the arsenic status in cardiovascular tissues of patients with coronary heart disease. Hum Exp Toxicol. 2011, 30, 1150-64.

[5] Pizarro I., Gómez M.M., Palacios M.A., Cámara C. Distribution of arsenic species in environmental samples collected of northern Chile. Intern J Environ Anal Chem 2003, 83, 879 - 890.

[6] Correa J.A., Ramírez M.A., De La Harpe J.P., Román D., Rivera L. Copper, copper mining effluents and grazing as potential determinants of algal abundance and diversity in Northern Chile. Environmental Monitoring and Assessment 2000, 61, $265-281$.

[7] Gavrilescu M.,Demnerová K.,Aamand J.,Agathos S.,Fava F.Emerging pollutants in the environment: present and future challenges in biomonitoring, ecological risks and bioremediation.New Biotechnology2015, 32, 147-156.

[8] Ferreccio C., Gonzalez P.C., Milosavjlevic S.V., Marshall G.C., Sancha A.M. Lung cancer and arsenic exposure in drinking water: A case - control study in Northern Chile. Cad Saude Publica 1998, 14, 193 - 198.

[9] USA National Research Council. Arsenic in drinking water. National Academy Press, Washington D. C., 2015. pp. $1-310$.

[10] Hopenhayn-Rich C, Browning S., Hertz I., Ferrecio C., Gibb H. Chronic arsenic exposure and risk of infant mortality in two areas of Chile. Environmental Health Perspectives 2000, 108, 667-73.

[11] Punshon T., Davis M.A.,Marsit C.J.,Theiler S.K.,Baker E.R., Jackson B.P.,Conway D.C.,Karagas. M.R. Placental arsenic concentrations in relation to both maternal and infant biomarkers of exposure in a US cohort.Environ Sci Technol. 2016, 50, 1587-1594.

[12] Tyler C.R., Allan A.M.The Effects of Arsenic Exposure on Neurological and Cognitive Dysfunction in Human and Rodent Studies: A Review.Curr Envir Health 2014, 1, 132-147.

[13]Lamm S. H., Ferdosi H., Dissen E. K., Li J., Ahn J. A Systematic Review and Meta-Regression Analysis of Lung Cancer Risk and Inorganic Arsenic in Drinking Water. J. Environ. Res. Public Health 2015, 12, 1549815515.

[14] Chung J.Y., Kim B.G., Lee B.K., Moon J.D., Sakong J., Jeon M.J., Park J.D., Choi B.S., Kim N.S., Yu S.D., Seo J.W., Ye B.J., Lim H.J., Hong Y.S. Urinary arsenic species concentration in residents living near abandoned metal mines in South Korea. Annals of Occupational and Environmental Medicine 2016, 67, 2 - 8.

[15] Smith A.H., Marshall G., Yuan Y., Liaw J., Ferreccio C., Steinmaus C. Evidence From Chile That Arsenic in Drinking Water May Increase Mortality From Pulmonary Tuberculosis. Am J Epidemiol 2011, 173, $414-420$.

[16] Tchounwou P.B., Patlolla A.K., Centeno J.A. Carcinogenic and systemic health effects associated with arsenic exposure-a critical review. Toxicol Pathol. 2003, 31, 575-588.

[17] Moon K., Guallar E., Navas-Acien A. Arsenic Exposure and Cardiovascular Disease: An Updated Systematic Review. Curr Atheroscler Rep. 2012, 14, $542-555$.
[18] Solar C., Pizarro I., Román D. Presencia de altos niveles de arsénico en tejidos cardiovasculares de pacientes de áreas contaminadas en Chile. Rev Chil Cardiol 2012, 31, 41-47.

[19] Navas-Acien A., Sharrett A.R., Silbergeld E.K., Schwartz B.S., Nachman K.E., Burke T.A., Guallar E.Arsenic exposure and cardiovascular disease: A systematic review of the epidemiologic evidence. Am J Epidemiol 2005, 162, 1 - 13.

[20] Hata A., Kurosawa H., Endo Y., Yamanaka K., Fujitani N., Endo G. A biological indicator of inorganic arsenic exposure using the sum of urinary inorganic arsenic and monomethylarsonic acid concentrations. J Occup Health 2016, 58,196-200.

[21]Zhang H., Ge Y., He P., Chen X., Carina A., Qiu Y., Aga, D.S., Ren X. Interactive Effects of N6AMT1 and As3MT in Arsenic Biomethylation. Toxicological Sciences 2015, 146, 354- 362.

[22] Stýblo M., Drobna Z., Jaspera I., Lin S., Thomas D. J. The role of biomethylation in toxicity and carcinogenicity of arsenic: A research update. Environ. Health Perspect. 2002, 110,767 - 71 .

[23] Benramdane L., Accominotti M., Fanton L., Malicier D., Vallon J. Arsenic speciation in human organs following fatal arsenic trioxide poisoning - a case report. Clin Chem 1999, 45, 301 - 306.

[24]Ekpenyong C. E. Essential Trace Element and Mineral Deficiencies and Cardiovascular Diseases: Facts and Controversies. International Journal ofNutrition and Food Sciences 2017, 6, 53-64.

[25] Simsek N., Akinci L.,Alan H., Gecör O.,Özan Ü. Determination of trace elements in kidneys, livers and brains of rats with sealer implants by ICP-MS. Biotechnology \&Biotechnological Equipment 2017, 31, 397-402.

[26] Pizarro I., Gómez M., Cámara C., Palacios M.A., Román - Silva D.A. Evaluation of arsenic species protein binding in cardiovascular tissues by bidimensional chromatography with ICP - MS detection. J Anal At Spectrom 2004, 19, 292 - 296.

[27] Pizarro I., Román-Silva D. A., Gómez M.M., Cámara C., Palacios M. A. Arsenic Species-binding Proteins in Human Cardiovascular and Muscle Tissues, J. Chil. Chem. Soc. 2013, 58, 2071-76.

[28] Ng J.C. Environmental contamination of arsenic and its toxicological impact on humans. Environ Chem 2005, $2,146-160$.

[29] Signes-Pastor A., Carey M., Vioque J., NavarreteMuñoz E.M., Rodríguez-Dehli C., Tardón A., BegoñaZubero M., Santa-Marina L., Vrijheid M., Casas M., Llop S., Gonzalez-Palacios S., Meharg A,A. Urinary Arsenic Speciation in Children and Pregnant Women from Spain. Expo Health 2017, 9, 105-111.

[30] Taylora V., Goodalea B.,Raabb A.,Schwerdtlec T.,Reimerd K.,Conkline S.,Karagasf M.R.,Francesconig K.A. Human exposure to organic arsenic species from seafood.Science of the Total Environment 2017, 580, 266-282.

[31] Yu G., Sun D., Zheng Y. Health effects of exposure to natural arsenic in groundwater and coal in China: An overview of occurrence. Environ Health Perspect 2007, $15,636-652$. 


\section{International Journal of Science and Research (IJSR) \\ ISSN (Online): 2319-7064 \\ Index Copernicus Value (2016): 79.57 | Impact Factor (2015): 6.391}

[32] Komatina M.M. Effects of Geological Environments on Human Health. Medical Geology...Developments in Earth \& Environmental Sciences, Vol. 2. Elsevier, Amsterdam, 2004, pp 488.

[33] Selinus B., Alloway J.A., Centeno R.B., Finkelman R.F., Smedley V.P. Essential of Medical Geology. Impacts of the Natural Environmental on Public Health (Elsevier, U. S. A. London, 2005).

[34] Bunnell J.E., Finkelman R.B., Centeno J.A., Selinus O. Medical Geology: a globally emerging discipline. Geol Acta 2007, 5, $273-281$.

[35] Welz B., Melcher M. Decomposition of marine biological tissues for determination of arsenic, selenium, and mercury using hydride-generation and cold - vapor atomic absorption spectrometry. Anal. Chem. 1985, 57, 427 - 31.

[36] United Nations Environmental Program (UNEP). Determination of Total Selenium in Selected Marine organisms by Hydride Generation Atomic Absorption Spectrometry. Reference Method for Marine Pollution Studies No 10, 1984.

[37] Shibata Y., Morita M. Characterization of organic arsenic compounds in bivalves. Appl. Organomet Chem. 1992, 6, $340-43$.

[38]Long G.L., Winefordner J.D. Limit of Detection A Closer Look at the IUPAC Definition. Anal. Chem., 1983, 55, 712-24.

[39] Currie L.A. Detection and quantification limits: origins and historical overview. Analytica Chimica Acta 1999, 391, 127-134.

[40] Beauchemin D, Bednas M.E., Berman S.S., McLaren J.W., Siu K.W.M., Sturgeon R.E. Identification and quantitation of arsenic species in a dogfish muscle reference material for trace elements. Anal Chem 1988, 60, $2209-2212$.

[41] Shibata Y., Morita M. Exchange of comments on identification and quantitation of arsenic species in a dogfish muscle reference material for trace elements. Anal. Chem 1989, 61, 2116-2118.

[42] Gallagher P.A., Murray S., Wei X., Schwegel C.A., Creed J.T. An evaluation of sample dispersion media used with accelerated solvent extraction for the extraction and recovery of arsenicals from LFB and DORM-2. J Anal At Spectrom 2002, 17, 581 - 586.

[43]Chong W. CH., Wu R., Tu Y. A Study on Tissue Processing. International Journal of Innovative Interdisciplinary Research 2012, 3, 37-43.

[44]Coufal O., Ostřižek T., Krsička P., Lžičařová E., Nenutil R., Procházková M., Bencsiková B., Grell P., Šefr R. Focal necrosis mimicking breast cancer following coronary bypass grafting. . World Journal of Surgical Oncology 2017, 111,1-4.

[45] Kanduc D., Mittelman A., Serpico R., Sinigaglia E., Sinha A.A., Natale C., Santacroce R., G. Di Corcia M., Lucchese A., Dini L., Pani P., Santacroce S, Simone S., Bucci R., Farber E. Cell death: Apoptosis versus necrosis (Review). International Journal of Oncology 2002, 21,165-170.

[46] Pizarro I., Román D., Gómez M.M., Palacios M.A. Arsenic Status and Speciation in Chicken Heart Tissues.J. Chil. Chem. Soc. 2015, 60, 2664 - 26670.
[47] Chris L. X., Mingsheng M., Xiufen L., Cullen W. R., Aposhian H.V., Zheng B. Determination of monomethylarsonous acid a key arsenic methylation intermediate in human urine. Environ. Health Perspect. 2000,108, 1015-1018.

[48] Tseng CH. Metabolism of inorganic arsenic and noncancerous health hazards associated with chronic exposure in humans. J Environ Biol. 2007, 28, 349 357.

[49] Larsen E.H., Pritzl G., Hansen S.H. Speciation of eight arsenic compounds in human urine by highperformance liquid chromatography with inductively coupled plasma mass spectrometric detection using antimonite for internal chromatographic standardization. J Anal Atom Spectrom. 1996, 8, 557 - 563.

[50] Chang K.N., Lee T.Ch.. Tam M.F., Chen Y.ch., Lee L.W., Lee S.Y., Lin P.J., Huang R.N. Identification of galectin I thioredoxin peroxidase II as two arsenic binding proteins in Chinese hamster ovary cells. Biochem J. 2003, 371, 495 - 503.

[51]Law J.A., Jacobsen S.E. Establishing, maintaining and modifying DNA methylation patterns in plants and animals. Nat Rev Genet. 2010, 11, 204-220

[52]Lin S., Shi Q., Nix F.B., Styblo M., Beck M. A., Herbin-Davis K.M., Hall L.L., Simeonsson J.B., Thomas D.J. A Novel S-Adenosyl-Lmethionine:Arsenic(III) Methyltransferase from Rat Liver Cytosol. J. Biol. Chem. 2002, 277, 10795-10803.

[53] Bogdan G., Sampayo A., Vasken H. Arsenic binding proteins of mammalian systems: I. Isolation of three arsenite - binding proteins of rabbit liver. Toxicology 1994, 93, 175 - 193.

[54] Kenyon E.M., Del Razo L.M., Hughes M. F. Tissue distribution and urinary excretion of inorganic arsenic and its methylated metabolites in mice following acute oral administration of arsenate. Toxicol Sci 2005,85, 468-475.

[55] Lee T.C., Ho I.C. Differential cytotoxic effects of arsenic on human and animal cells. Environ Health Perspect 1994, 102, $101-105$.

[56] Valenzuela O.L., Borja - Aburto V.H., García - Vargas G.G., Cruz - González M.B., García - Montalvo E. A., Calderón - Aranda E.S. Urinary trivalent methylated arsenic species in a population chronically exposed to Inorganic arsenic. Environ Health Perspect 2005,113, $250-254$

[57] Stýblo M., Hughes M., Thomas D. Liberation and analysis of protein bound arsenicals. J. Cromatogr B 1996, 677, $161-166$.

[58]Farrer B.T., McClure C.P., Penner-HahnJ.E., Pecoraro V. L. Arsenic (III) - cysteine interactions stabilize three-helix bundles in aqueous solution. Inorg Chem 2000, 39, $5422-5423$.

[59] Rosen B.P. Biochemistry of arsenic detoxification. FEBS Lett.2002, 529, 86 - 92. 


\section{International Journal of Science and Research (IJSR) \\ ISSN (Online): 2319-7064}

Index Copernicus Value (2016): 79.57 | Impact Factor (2015): 6.391

[60] Chiou J.M., Wang S.L., Chen Ch.J., Deng Ch.R., Lin W., Tai T.J. Arsenic ingestion and increased microvascular disease risk: Observations from the south - western arseniasis - endemic area in Taiwan. Int $\mathbf{J}$ Epidemiol, 2005,34, 936-943.

[61] Hughes M.F. Biomarkers of exposure: A case study with inorganic arsenic. Environ Health Perspect 2006, 114, $1790-1796$.

[62] Shen S., Li X.F., Cullen W.R., Weinfeld M., Le X. Ch. Arsenic Binding to Proteins. Chem. Rev. 2013,113, 7769-7792.

Volume 6 Issue 12, December 2017

www.ijsr.net

Licensed Under Creative Commons Attribution CC BY 